\title{
Postharvest Fumigation of 1-MCP Influences Cell Wall Degrading and Antioxidant Enzymes in Banana (Musa paradisiaca L.) Cv. Grand Naine during Storage
}

\author{
T. Kranthi Kumar*, B.V.K. Bhagavan, K. Mamatha, A. Snehalatha Rani and \\ P. Subbaramamma
}

Department of Fruit science, Dr. YSR Horticultural University, Venkataramannagudem 534101, Andhra Pradesh, India

*Corresponding author:

\section{A B S T R A C T}

\section{Keywords}

Postharvest fumigation, $1-\mathrm{MCP}$, Cell wall degrading

Article Info

Accepted:

24 November 2018

Available Online:

10 December 2018
In order to extend the shelf life of banana cultivar Grand Naine was fumigated with 1-methylcyclopropane (1-MCP) at four different concentrations $(100,200,300$ and 400 ppb) @ 24h exposed time and stored at ambient conditions. Among all the treatments, $400 \mathrm{ppb}$ was found to be an effective in extending shelf-life, highest retention of cell wall degrading enzyme such as Pectin methylestarase and free radical scavenging enzymes peroxidise and catalase. The entire 1-MCP treated banana showed better results over control (kept at open air @ 24h).

\section{Introduction}

Banana (Musa paradisiaca L.) is one of the major commercial fruit crop grown in tropics and subtropics. It plays a key role in the economy of developing countries. India has vast prospective to cultivate and produce the high quality banana fruits and are exported to the local markets instead of the international markets. Approximately 25 to $30 \%$ of the harvested fresh produce is deteriorated in every year due to high perishable nature of the fruits, pitiable handling practices and inadequate storage facilities. The causes for postharvest losses of fresh produce are an increase in respiration rate, ethylene production, physiological disorders and general senescence. Generally banana is classified as climacteric fruit which is characterized by a low rates of ethylene production and respiration during the preclimacteric phase, followed by a sudden burst in ethylene production and respiration rate during ripening (Burg and Burg, 1965). The 
sudden rises in respiration rate and ethylene production during ripening stage are responsible for major postharvest losses in bananas. Ethylene is a gaseous hormone, it accelerates the ripening in climacteric fruits. The ripening is mainly triggered through the action of ethylene binding to its receptor sites located on cell membrane (Sisler and Serek, 1997).

A novel gaseous anti-ethylene compound 1Methylcyclopropene (1-MCP) has been reported to have inhibitory effects on ethylene action (Serek et al., 1994, Sisler et al., 1995). It is a stable powder and easily released the ethylene gas when dissolved in water. It acts by binding irreversibly to ethylene-receptors hence, subsequent signal transduction and translation responses are not elicited, causes fruits to be ripen and soften more slowly, thereby maintaining the quality of produce for longer period. 1-MCP treatment extended the green life and/or inhibited the ripening of tomato, banana and plum fruits (Serek et al., 1995, Sisler et al., 1995, Macnish et al., 1997, Abdi et al., 1998, Golding et al., 1998).

In this present paper, we have investigated the effects of 1-MCP on banana fruit ripening by measuring cell wall degrading enzyme i.e. pectin methylestarase and antioxidant enzymes such as catalase and peroxidases.

\section{Materials and Methods}

\section{Plant material and treatments}

The current research work was carried out in the in the Department of Fruit Science, College of Horticulture, V.R. Gudem, Dr. YSRHU during the year 2015-18. Mature green (80-85\% Maturity) Grand Naine banana bunches were harvested from the experimental farm field of HRS, Kovvur, Dr. YSRHU. Later harvested bunches are dehanded carefully and second hand from each bunch brought to the laboratory. Then the hands were cleaned in tap water, dipped in $0.1 \%$ Bavistin for a while and air dried under fan for 10-15 minutes. Later the banana hands were placed in known volume carton boxes (CFB) for imposing 1-MCP. The required quantity of 1MCP Ansip-F tablets for known volume carton boxes for yielding $100 \mathrm{ppb}, 200 \mathrm{ppb}$, $300 \mathrm{ppb}$ and $400 \mathrm{ppb}$ were calculated $(1.1 \mathrm{~g}$ of tablet in 40L carton box gives $900 \mathrm{ppb}$ concentration) and crushed into powder with mortar and pestle. The 1-MCP powder was placed inside the flask containing a rubber septum. Then warm distilled water (at 40$50^{\circ} \mathrm{C}$ ) was added to the flask for dissolving the 1-MCP powder. The flask was then placed inside the container through the top opening and the flask lid is removed immediately before the carton box was completely sealed. This modified method was described by Wongmetha and Lih-Shang Ke (2012) and Alves et al., (2005). After exposure to $24 \mathrm{hrs}$ at room temperature the carton boxes were opened and the banana hands were kept for storage studies at ambient room temperature $\left(32 \pm 2^{\circ} \mathrm{C}\right.$ and $\left.78 \pm 2 \% \mathrm{RH}\right)$. The banana fruits were sampled for enzyme analysis at 3 day interval. The treatments attempted in this experiment were 1-Methylcyclopropene (100 ppb), 1-Methylcyclopropene (200 ppb), 1Methylcyclopropene (300 ppb) and 1Methylcyclopropene (400 ppb) along with control (kept at open air @24h).

\section{Observations recorded}

\section{Determination of pectin methylesterase (PME) activity}

Pectin methylesterase (PME) activity in banana fruit pulp was measured following the method of Hagerman and Austin (1986) with minor modifications. The method is based on the colour change of a $\mathrm{pH}$ indicator during the PME catalysed reaction. In a cuvette, $2.0 \mathrm{~mL}$ of pectin $(0.5 \%)$ is mixed with $0.15 \mathrm{~mL}$ of 
bromothymol blue $(0.01 \%)$ and $0.83 \mathrm{~mL}$ of water. The absorbance of the mixture is read against water as blank at $620 \mathrm{~nm}$. A constant value of A620 at this stage indicates nonexistence of non-enzymatic hydrolysis. The reaction is started by adding $50 \mu \mathrm{L}$ of enzyme solution and the rate of decrease in A620 was recorded. The acid produced by PME action lowers the $\mathrm{pH}$ of the medium and thereby cause protonation of the indicator dye to produce a change in absorbance at $620 \mathrm{~nm}$. The change in absorbance is continuously monitored spectrophotometrically and the initial rate of reaction is determined. A standard graph is plotted (OD vs. time) using different known concentrations of glacial acetic acid and the rate of reaction is determined from the linear portion of the graph. The PME activity was expressed as $\mu \mathrm{mol} \min ^{-1} \mathrm{~g}^{-1} \mathrm{FW}$.

\section{Determination of catalase and peroxidase activity}

Extract for determination catalase (CAT) and peroxidase (POD) activities were prepared from $0.3 \mathrm{gm}$ of banana pulp, homogenized with a pre-chilled mortar and pestle under ice cold condition in $3 \mathrm{ml}$ of extraction buffer, containing $50 \mathrm{mM}$ sodium phosphate buffer ( $\mathrm{pH}$ 7.4) with the addition of $1 \mathrm{mM}$ EDTA and $1 \%$ (W/V) polyvinylpyrolidone (PVP). The homogenates were centrifuged at 10,000 rpm for 20 minutes and the supernatant was used for the assay (Costa et al., 2002).

Total catalase (EC 1.11.1.6) activity was determined in the homogenates by measuring the decrease in absorption in $3 \mathrm{ml}$ mixture at $240 \mathrm{~nm}$ as $\mathrm{H}_{2} \mathrm{O}_{2}\left(\varepsilon=39.4 \mathrm{mM}^{-1} \mathrm{~cm}^{-1}\right)$ was consumed according the method of Aebi (1984) and enzyme activity expressed as $\mu \mathrm{M}$ $\mathrm{H}_{2} \mathrm{O}_{2}$ oxidized $\mathrm{min}^{-1} \mathrm{mg}^{-1}$ protein. The $3 \mathrm{ml}$ mixture containing $50 \mathrm{mM}$ sodium phosphate buffer $(2 \mathrm{ml})(\mathrm{pH} 7.0), 10 \mathrm{mM} \mathrm{H}_{2} \mathrm{O}_{2}(950 \mu \mathrm{l})$ and $50 \mu$ enzyme extract.
POD (EC 1.11.1.7) activity was determined in the homogenates by measuring the increase in absorption at $470 \mathrm{~nm}$ due to the formation of tetraguaiacol $\left(\varepsilon=26.6 \mathrm{mM}^{-1} \mathrm{~cm}^{-1}\right)$ in a $3 \mathrm{ml}$ reaction mixture containing $50 \mathrm{mM}$ sodium phosphate buffer $(2 \mathrm{ml}) \mathrm{pH} 7.0,0.1 \mathrm{mM}$ EDTA $(100 \mu \mathrm{l}), \quad 0.1 \mathrm{ml}$ enzyme extract, $10 \mathrm{mM}$ guaiacol $(400 \mu \mathrm{l})$ and $10 \mathrm{mM} \mathrm{H}_{2} \mathrm{O}_{2}(400 \mu \mathrm{l})$ (Costa et al., 2002) and enzyme activity expressed as $\mu \mathrm{mol}$ guaiacol oxidized $\mathrm{min}^{-1}$ $\mathrm{mg}^{-1}$ protein.

\section{Shelf life (d)}

The shelf life of fruits was determined by recording the number of days the fruits remained in good condition during storage. The stage at which more than 50 per cent of the stored fruits became unfit for consumption was considered as end of shelf life in that particular treatment and expressed as mean number of days (Padmalatha, 1993).

\section{Statistics}

The experiment was designed in a factorial completely randomized design (FCRD) with three replications. The data was analyzed as per the design and the results were compared from the CD value obtained through ANOVA (Panse and Sukhatme 1984).

\section{Results and Discussion}

\section{Pectin methylesterase (PME) activity}

PME activity was followed an increasing trend in all treatments from $1^{\text {st }}$ to $10^{\text {th }}$ day of storage. However, the rate of increase was significantly high in the untreated banana compared to the treated ones (Table 1 and Fig. 1). Maximum ( $\left.0.273 \mu \mathrm{mol} \mathrm{min} \mathrm{m}^{-1} \mathrm{FW}\right)$ PME activity was noticed in untreated banana and minimum in fruits fumigated with 1-MCP @ $400 \mathrm{ppb}\left(0.106 \mu \mathrm{mol} \mathrm{min} \mathrm{g}^{-1} \mathrm{FW}\right)$, followed by 1-MCP @ $300 \mathrm{ppb}\left(0.130 \mu \mathrm{mol} \mathrm{min}^{-1} \mathrm{~g}^{-1}\right.$ 
FW). However, the PME activity continually increased but at a slower pace in the banana fruits fumigated with 1-MCP. The reduced PME activity in the 1-MCP treated banana fruits can be attributed to retarding effects of 1-MCP on the fruit softening. Our results find the support from the reports of Lohani et al., (2004), who found lowered PG and PME enzyme activities in 1-MCP treated banana compared to the untreated fruits. Similar effects of 1-MCP on PME activity of plum (Khan and Singh 2007; Sharma et al., 2012) and papaya (Ahmad et al., 2013) have also been reported.

\section{Peroxidase (POD) activity}

Peroxidase activity was followed an produced.

Table.1 Effect of postharvest fumigation of 1-MCP on pectin methylestarase ( $\mu$ mol min-1g-1 $\mathrm{FW})$ in Grand Naine banana stored at ambient conditions $\left(32 \pm 2^{\circ} \mathrm{C}\right.$ and $\left.78 \pm 2 \% \mathrm{RH}\right)$

\begin{tabular}{|c|c|c|c|c|c|}
\hline \multirow[t]{2}{*}{ Treatments $(\mathbf{T})$} & \multicolumn{5}{|c|}{ Storage Period(S) } \\
\hline & $1^{\text {st }}$ Day & $4^{\text {th }}$ Day & $7^{\text {th }}$ Day & $10^{\text {th }}$ Day & Mean \\
\hline 1-MCP@100 ppb & 0.136 & 0.181 & 0.226 & 0.310 & 0.213 \\
\hline 1-MCP @ 200 ppb & 0.101 & 0.114 & 0.135 & 0.222 & 0.143 \\
\hline 1-MCP @ 300 ppb & 0.092 & 0.108 & 0.117 & 0.201 & 0.130 \\
\hline 1-MCP@ 400 ppb & 0.080 & 0.091 & 0.105 & 0.147 & 0.106 \\
\hline Control (open air) & 0.184 & 0.215 & 0.291 & 0.403 & 0.273 \\
\hline \multirow[t]{2}{*}{ Mean } & 0.119 & 0.142 & 0.175 & 0.257 & \\
\hline & \multicolumn{2}{|c|}{ SE(m) } & \multicolumn{2}{|c|}{ C.D.@5\% } & \\
\hline Treatment & \multicolumn{2}{|c|}{0.001} & \multicolumn{2}{|c|}{0.002} & \\
\hline Storage Period & \multicolumn{2}{|c|}{0.001} & \multicolumn{2}{|c|}{0.002} & \\
\hline $\mathbf{T} \times \mathbf{S}$ & \multicolumn{2}{|c|}{0.002} & \multicolumn{2}{|c|}{0.005} & \\
\hline
\end{tabular}

Table.2 Influence of postharvest fumigation of 1-MCP on peroxidise ( $\mu$ mol min-1 mg-1 protein) in Grand Naine banana stored at ambient conditions $\left(32 \pm 2^{\circ} \mathrm{C}\right.$ and $\left.78 \pm 2 \% \mathrm{RH}\right)$

\begin{tabular}{|c|c|c|c|c|c|}
\hline \multirow[t]{2}{*}{ Treatments $(\mathbf{T})$} & \multicolumn{5}{|c|}{ Storage Period(S) } \\
\hline & $1^{\text {st }}$ Day & $4^{\text {th }}$ Day & $7^{\text {th }}$ Day & $10^{\text {th }}$ Day & Mean \\
\hline 1-MCP @ 100 ppb & 0.081 & 0.106 & 0.214 & 0.512 & 0.228 \\
\hline 1-MCP@200 ppb & 0.038 & 0.064 & 0.112 & 0.190 & 0.101 \\
\hline 1-MCP@300 ppb & 0.032 & 0.053 & 0.085 & 0.130 & 0.075 \\
\hline 1-MCP @ 400 ppb & 0.021 & 0.037 & 0.061 & 0.105 & 0.056 \\
\hline Control (open air) & 0.095 & 0.182 & 0.278 & 0.832 & 0.347 \\
\hline \multirow[t]{2}{*}{ Mean } & 0.053 & 0.088 & 0.150 & 0.354 & \\
\hline & \multicolumn{2}{|c|}{ SE(m) } & \multicolumn{2}{|c|}{ C.D.@5\% } & \\
\hline Treatment & \multicolumn{2}{|c|}{0.001} & \multicolumn{2}{|c|}{0.003} & \\
\hline Storage Period & \multirow{2}{*}{\multicolumn{2}{|c|}{0.001}} & \multicolumn{2}{|c|}{0.003} & \\
\hline$T \times S$ & & & \multicolumn{2}{|c|}{0.006} & \\
\hline
\end{tabular}




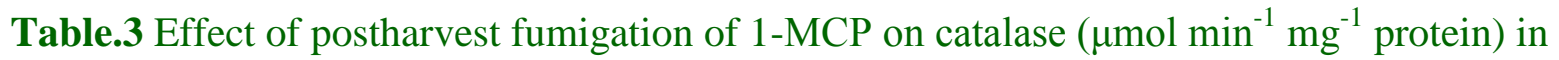
Grand Naine banana stored at ambient conditions $\left(32 \pm 2{ }^{\circ} \mathrm{C}\right.$ and $\left.78 \pm 2 \% \mathrm{RH}\right)$

\begin{tabular}{|c|c|c|c|c|c|}
\hline \multirow[t]{2}{*}{ Treatments (T) } & \multicolumn{5}{|c|}{ Storage Period(S) } \\
\hline & $1^{\text {st }}$ Day & $4^{\text {th }}$ Day & $7^{\text {th }}$ Day & $10^{\text {th }}$ Day & Mean \\
\hline 1-MCP @ 100 ppb & 1.940 & 2.680 & 3.900 & 6.470 & 3.748 \\
\hline 1-МCP @ 200 ppb & 1.200 & 1.830 & 2.850 & 4.380 & 2.565 \\
\hline 1-МCP @ 300 ppb & 1.020 & 1.350 & 2.030 & 2.400 & 1.700 \\
\hline 1-MCP@ 400 ppb & 0.880 & 1.020 & 1.640 & 1.870 & 1.353 \\
\hline Control (open air) & 1.890 & 3.270 & 5.170 & 7.030 & 4.340 \\
\hline \multirow[t]{2}{*}{ Mean } & 1.386 & 2.030 & 3.118 & 4.430 & \\
\hline & \multicolumn{2}{|c|}{ SE(m) } & \multicolumn{2}{|c|}{ C.D.@5\% } & \\
\hline Treatment & \multicolumn{2}{|c|}{0.013} & \multicolumn{2}{|c|}{0.038} & \\
\hline Storage Period & \multicolumn{2}{|c|}{0.012} & \multicolumn{2}{|c|}{0.034} & \\
\hline $\mathbf{T} \times \mathbf{S}$ & \multicolumn{2}{|c|}{0.027} & \multicolumn{2}{|c|}{0.077} & \\
\hline
\end{tabular}

Table.4 Influence of postharvest fumigation of 1-MCP on shelf life (d) in Grand Naine banana stored at ambient conditions $\left(32 \pm 2^{\circ} \mathrm{C}\right.$ and $\left.78 \pm 2 \% \mathrm{RH}\right)$

\begin{tabular}{|c|c|}
\hline Treatments (T) & Shelf life (d) \\
\hline 1-MCP @ 100 ppb & 12.95 \\
\hline 1-MCP @ 200 ppb & 15.94 \\
\hline 1-MCP @ 300 ppb & 19.93 \\
\hline 1-MCP @ 400 ppb & 20.92 \\
\hline Control (open air) & 9.96 \\
\hline SE(m) & 0.11 \\
\hline C.D.@5\% & 0.34 \\
\hline
\end{tabular}

Fig.1 Effect of postharvest fumigation of 1-MCP on pectin methylestarase ( $\mu$ mol $\left.\mathrm{min}^{-1} \mathrm{~g}^{-1} \mathrm{FW}\right)$ in Grand Naine banana stored at ambient conditions $\left(32 \pm 2^{\circ} \mathrm{C}\right.$ and $\left.78 \pm 2 \% \mathrm{RH}\right)$

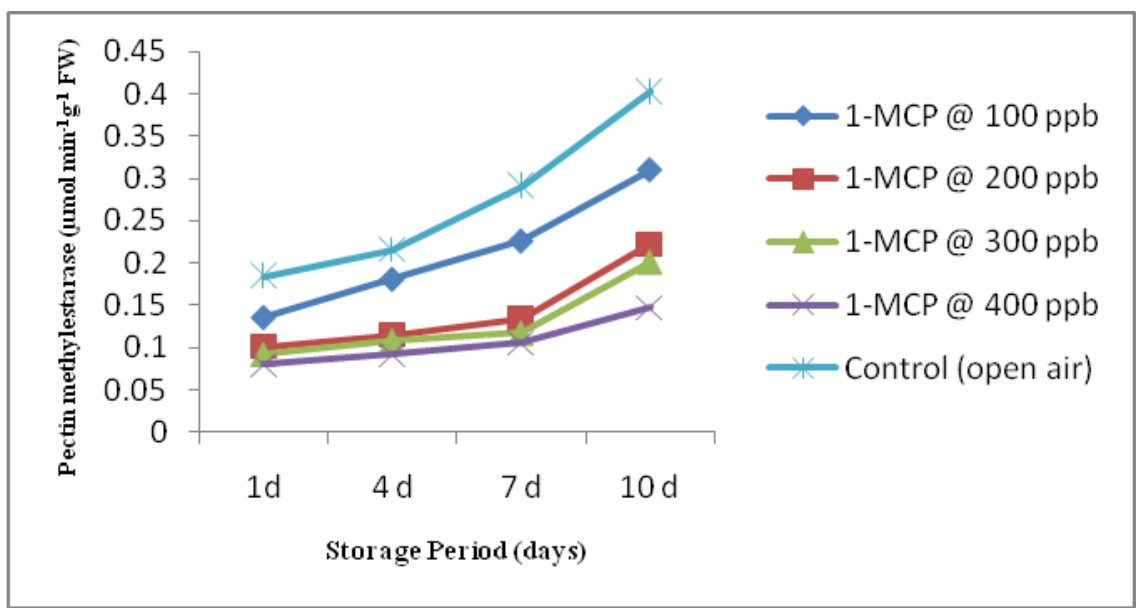


Fig.2 Influence of postharvest fumigation of 1-MCP on peroxidise ( $\mu \mathrm{mol} \mathrm{min} \mathrm{mg}^{-1}$ protein) in Grand Naine banana stored at ambient conditions $\left(32 \pm 2{ }^{\circ} \mathrm{C}\right.$ and $\left.78 \pm 2 \% \mathrm{RH}\right)$

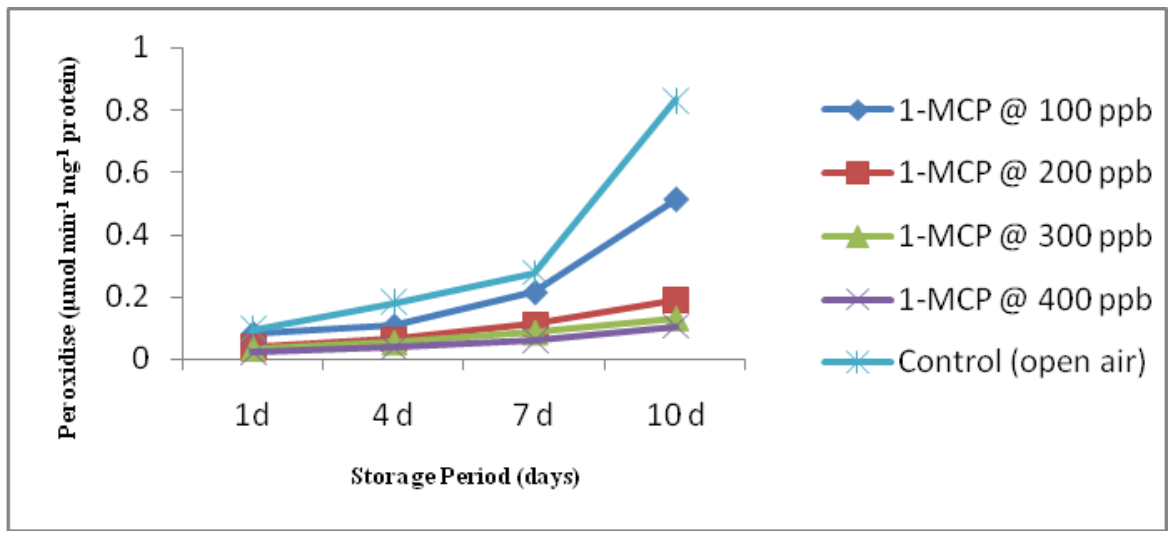

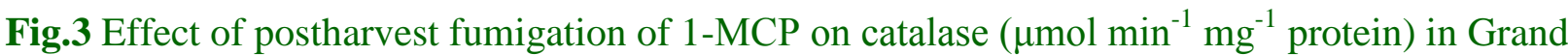
Naine banana stored at ambient conditions $\left(32 \pm 2^{\circ} \mathrm{C}\right.$ and $\left.78 \pm 2 \% \mathrm{RH}\right)$

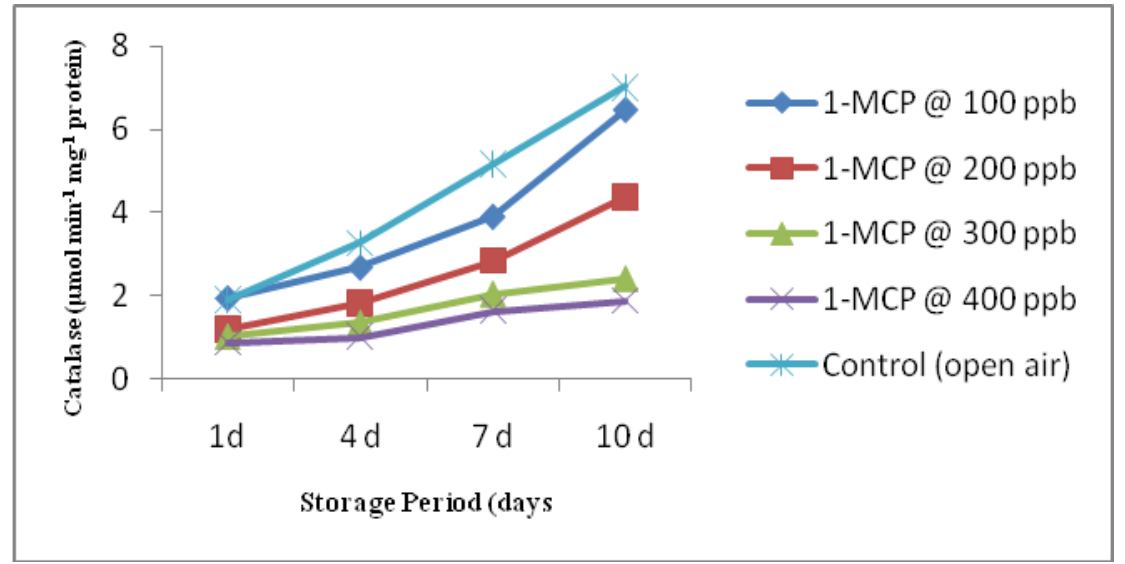

Fig.4 Influence of postharvest fumigation of 1-MCP on shelf life (d) in Grand Naine banana stored at ambient conditions $\left(32 \pm 2^{\circ} \mathrm{C}\right.$ and $\left.78 \pm 2 \% \mathrm{RH}\right)$

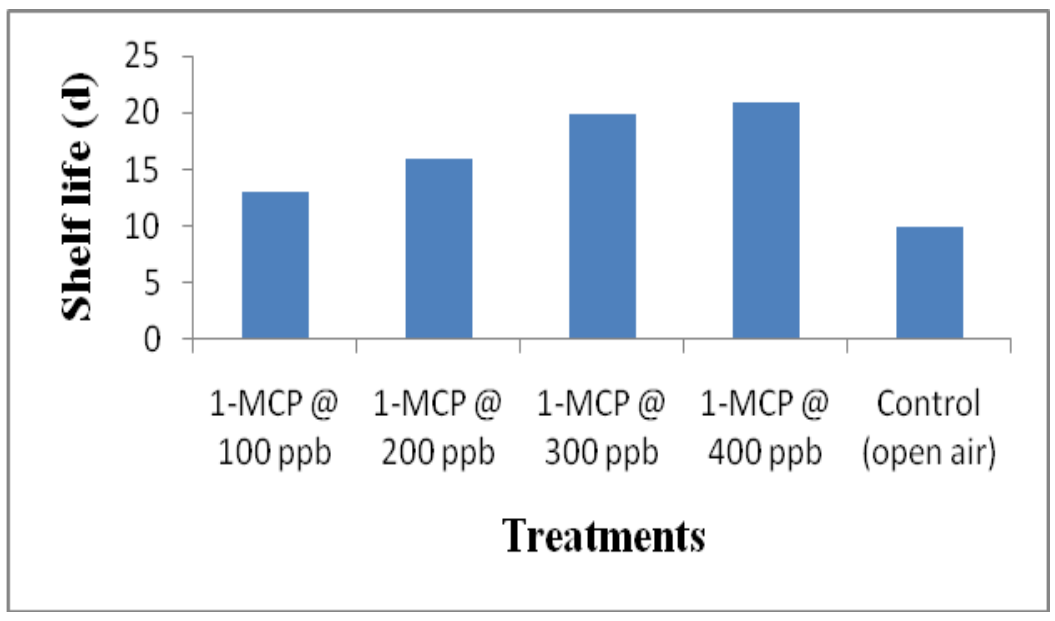


In this present investigation 1-MCP treated banana fruits recorded less amount of peroxidise (POD) when compared to untreated bananas, this is may be due to delayed ripening process caused by binding of 1-MCP with ethylene receptor that resulted in an apparent delay in the onset of elevated ethylene evolution and respiration rates and also delay in several physiological responses related to ripening. The results obtained under the present investigation are also in agreement with the findings of Dal Cin et al., (2006) and Wang et al., (2009).

\section{Catalase (CAT) activity}

Catalase activity was followed an increasing trend in all treatments from $1^{\text {st }}$ to $10^{\text {th }}$ day of storage. However, the rate of increase was significantly high in the untreated banana compared to the treated ones (Table 3 and Fig. 3). Maximum (4.340 $\mu \mathrm{mol} \mathrm{min} \mathrm{mg}^{-1}$ protein) CAT activity was noticed in untreated banana and minimum in fruits fumigated with 1-MCP @ 400 ppb (1.353

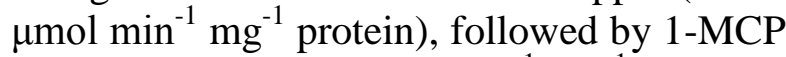
(a) $300 \mathrm{ppb}\left(1.700 \mu \mathrm{mol} \mathrm{min} \mathrm{mg}^{-1}\right.$ protein). However, the catalase activity continually increased but at a slower pace in the banana fruits fumigated with 1-MCP. The reduced CAT content in 1-MCP treated banana fruits can be attributed directly to its ability in inhibiting ethylene action and also to the role of ethylene in triggering free radicals (ROS) production. Such effects of 1-MCP leads to decreased ROS, maintained plasma membrane permeability and decreased the free radical scavenging enzymes production (CAT, POD and SOD). The different effects of 1-MCP on ROS and the antioxidant enzymes may be linked with $\mathrm{H}_{2} \mathrm{O}_{2}$ and AsA metabolism (production and degradation) (Wang et al., 2009). This effect was also observed in the previous studies (Larrigaudiere, et al., 2004) pear and (Dong et $a l ., 2002)$ apricot and plum.

\section{Shelf life}

Maximum shelf life (20.92 d) was recorded in Grand naine banana treated with 1-MCP @ $400 \mathrm{ppb}(\mathrm{d})$ and lowest shelf life (9.96 d) was recorded in untreated banana. All the 1-MCP treated banana fruits showed improved shelf life compared to control (Table 4 and Fig. 4). The reason for high concentration of 1-MCP was effective in order to suppress the more ethylene binding sites developed in the banana fruit tissues during ripening. These findings are in conformity with, Jiang et al., (1999), Jansasithorn and Kanlayanarat, (2006), Moradinezhad et al., (2006, 2010) and Krishna kumar and Thirupathi, (2014) in banana.

It was concluded that exposure of Grand naine banana fruits to 1-methylcyclopropane extended the economic shelf life at ambient conditions $\left(32 \pm 2{ }^{\circ} \mathrm{C}\right.$ and $\left.78 \pm 2 \% \mathrm{RH}\right)$ compared to the untreated control fruits. 1MCP (400 ppb) retained cell wall degrading enzyme (PME) and antioxidant enzymes (POD and CAT) and delayed the climacteric ripening process to a greater extent compared to other concentrations.

\section{References}

Abdi, N., McGlasson, W.B., Holford, P., Williams, M and Mizrahi, Y. 1998. Responses of climacteric and suppressed- climacteric plums to treatment with propylene and 1 methylcyclopropene. Postharvest Biological Technology. 14: 29- 39.

Aebi, H. 1984. Catalase in vitro. Methods in Enzymology. 105: 121-26.

Ahmad, A., Mohd Ali, Z and Zainal, Z. 2013. Delayed softening of papaya (Carica papaya L. cv. Sekaki) fruit by 1methylcyclopropene (1- MCP) during ripening at ambient and low 
temperature storage conditions. Australia Journal of Crop Science. 7: 750-57.

Alves, R.E., Filgueiras, H.A.C., Almeida, A.S., Machado, F.L.C., Bastos, M.S.R., Lima, M.A.C., Terao, D., Silva, E.O., Santos, E.C., Pereira, M.E.C and Miranda, M.R.A. 2005. Postharvest use of 1-MCP to extend storage life of melon in Brazil - current research status. Acta Horticulturae. 682: 223337.

Burg, S.P and Burg, E.A. 1965. Relationship between ethylene production and ripening in bananas. Botanical Gazette. 126: 200-04.

Costa, H., Gallego, S.M and Tomaro, M.L 2002. Effect of UV-B radiation on antioxidant defense system in sunflower cotyledons. Plant Science. 62: 939- 45.

Dal Cin, V., Rizzini, F.M., Botton, A and Tonutti, P. 2006. The ethylene biosynthetic and signal transduction pathways are differently affected by 1 MCP in apple and peach fruit. Postharvest Biology and Technology. 42: 125-33.

Dong, L., Lurie, S and Zhoa, H. 2002. Effect of 1-methylcyclopropane on ripening of "Canino" apricots and "Royal Zee" plums. Postharvest Biology and Technology. 24: 135-45.

Golding, J.B., Shearer, D., Wyllie, S.G and McGlasson, W.B. 1998. Application of $1-\mathrm{MCP}$ and propylene to identify ethylene-dependent ripening processes in mature banana fruit. Postharvest Biological Technology. 14: 87-98.

Hagerman, A.E and Austin, P.J 1986. Continuous spectrophotometry assay for plant pectin Methylesterase. Journal of Agriculture and Food Chemistry. 34: 440-44.

Jansasithorn, R and Kanlayanarat, S. 2006. Effect of 1-MCP on physiological changes in Banana Khai. Acta
Horticulture. 712: 723-27.

Jiang, Y., Joyce, D.C and Macnish, A.J. 1999. Responses of banana fruit to treatment with 1-methylcyclopropene. Plant Growth Regulator. 28:77-82.

Khan, A.S and Singh, Z. 2007. 1-MCP regulates ethylene biosynthesis and fruit softening during ripening of 'Tegan Blue' plum. Postharvest Biology and Technology. 43: 298-06.

Kumar, T.K and Thirupathi, V. 2014. Effect of 1-Methylcyclopropene (1-MCP) on Postharvest Quality and Shelf Life of Partially Ripened Bananas. Trends in Biosciences. 7(22): 3680-86.

Larrigaudiere, C., Vilaplana, R., Soria, Y and Recasens, I. 2004. Oxidative behaviour of Blanquilla pears treated with 1methyl -cyclopropene during cold storage. Journal of Science and Food Agriculture. 84: 1871-77.

Lohani, S., Trivedi, P.K and Nath, P. 2004. Changes in activities of cell wall hydrolases during ethylene-induced ripening in banana: effect of 1-MCP, $\mathrm{ABA}$ and IAA. Postharvest Biology and technology. 31: 119-26.

Macnish, A.J., Joyce, D.C and Hofman, P.J. 1997. 1-Methylcyclopropene delays ripening of 'Cavendish' banana fruit. Proceedings of the Australasian Postharvest Horticulture Conference. Australian Society of Horticultural Science, University of Western Sydney, Hawkesbury, NSW, Australia. pp. 282 84.

Moradinezhad, F., Klieber, A and Able, A.J. 2010. Effect of ripening temperatures on shelf life and quality of partially ripened 1-MCP treated bananas. Acta Horticulture. 877: 353-57.

Padmalatha, V. 1993. Studies on post harvest storage life of grapes (Vitis vinefera). M.Sc. Thesis submitted to Acharya N.G. Ranga Agricultural University, Hyderabad. 
Panse, V.G and Sukhatme, P.V. 1984. Statistical methods for agricultural workers. 3rd edition, Indian Council of Agricultural Research, New Delhi.

Serek, M., Sisler, E.C and Reid, M.S. 1994. Novel gaseous ethylene binding inhibitor prevents ethylene effects in potted flowering plants. Journal of American Society Horticultural Science. 119: 1230- 33.

Serek, M., Sisler, E.C and Reid, M.S. 1995. 1Methylcyclopropene, a novel gaseous inhibitor of ethylene action, improves the life of fruits, cut flowers and potted plants. Acta Horticulture. 394: 337-45.

Sharma, S., Sharma, R.R., Pal, R.K., Paul, V and Dahuja, A. 2012. 1Methylcyclopropene influences biochemical attributes and fruit softening enzymes of 'Santa Rosa' Japanese plum (Prunus salicina Lindl.). Journal of Plant Biochemistry and Biotechnology. 21: 295-99.
Sisler, E.C and Serek, M. 1997. Inhibitors of ethylene responses in plants at the receptor level: recent developments. Physiol. Plant. 100: 577-82.

Sisler, E.C., Serek, M and Dupille, E. 1995. Comparison of cyclopropene, 1 methylcyclopropene, and 3,3dimethylcyclopropene as ethylene antagonists in plants. Plant Growth Regulator. 17: 1-6.

Wang, B., Wang, J., Feng, X., Lin, L., Zhao, Y and Jiang, W. 2009. Effects of 1MCP and exogenous ethylene on fruit ripening and antioxidants in stored mango. Plant growth Regulation. 57(2): 185-92.

Wongmetha, O and Lih-Shang Ke. 2012. The quality maintenance and extending storage life of mango fruit after postharvest treatments. World Academy of Science, Engineering and Technology. 69: 936-41.

\section{How to cite this article:}

Kranthi Kumar, T., B.V.K. Bhagavan, K. Mamatha, A. Snehalatha Rani and Subbaramamma, P. 2018. Postharvest Fumigation of 1-MCP Influences Cell Wall Degrading and Antioxidant Enzymes in Banana (Musa paradisiaca L.) Cv. Grand Naine during Storage. Int.J.Curr.Microbiol.App.Sci. 7(12): 3145-3153. doi: https://doi.org/10.20546/ijcmas.2018.712.362 